\title{
Influence of fat supplementation in diets for bull-calves on growth rate and skeletal muscle metabolism
}

\author{
S Vovk ${ }^{1}, \mathrm{~V}$ Yanovych ${ }^{2}$ \\ 'Lviv State Agricultural Institute, Lviv-Dubliany 292040; 2Institute of Physiology and Biochemistry \\ of Animals, V Stus Street 38, Lviv 290034, Ukraine
}

Because of the high energetical value of fats and their regulatory influence on protein and lipid synthesis in skeletal muscles and other tissues of nonruminant animals, the investigation of productive and metabolic effect of dietary fats in ruminants has a great scientific and practical interest.

The purpose of our study was to investigate the influence of addition of tallow, sunflower oil or rapeseed oil to the diet of 30-180 day-old bull calves on growth, feed efficiency, total protein and lipid synthesis and oxidation of glucose, palmitate and leucine in skeletal muscles. Four groups of five bull calves of the black-piebald breed were used in the experiment. The calves of the first (control) group were offered a diet without fat supplementation. The animals of the second, third and fourth (experimental) groups were offered additionally $3 \%$ of tallow, sunflower oil or rapeseed oil respectively, on the dry matter basis. Once a month as well as at the beginning and at the end of the experimental period, the live weights of calves were measured. On the 45, 90, 150 and 180 days of age, samples of quadriceps femoris (oxidoglycolytic muscle) were excised by biopsy from three animals per group. Muscle homogenates were incubated (i) with $\mathrm{L}-\left[\mathrm{U}-{ }^{-14} \mathrm{C}\right]$ amino acid mixture for an hour to measure the intensity of total protein synthesis, (ii) with $\mathrm{L}-\left[\mathrm{U}-{ }^{14} \mathrm{C}\right]$ glucose to measure total lipid synthesis, (iii) with $\mathrm{L}-\left[\mathrm{U}-{ }^{14} \mathrm{C}\right]$ glucose, $\mathrm{L}-\left[\mathrm{U}-{ }^{14} \mathrm{C}\right]$ palmitate $\mathrm{Na}$ or $\mathrm{L}-\left[\mathrm{U}-{ }^{14} \mathrm{C}\right]$ leucine - to measure the oxidation rates of these substrates (Vovk and Yanovych, 1990, Biokhimia, 55, 11, 2090-2094).

The average daily gains of calves of the 1 st, $2^{\text {nd }}, 3^{\text {rd }}$ and $4^{\text {th }}$ groups were $777 \pm 29,921 \pm 44$, $903 \pm 31,902 \pm 19$ respectively (means $\pm S D$ ). However, the age of the animals did not influence daily gains considerably. The calves of the $2^{\text {nd }}, 3^{\text {rd }}$ and $4^{\text {th }}$ groups consumed 8.7 , 10.2 and $12.3 \%$ less quantity of feed per $\mathrm{kg}$ of weight gain than the control calves. Incorporation of radiolabeled amino acid into total muscle proteins was $58.6,24.4,24.1$ per cent higher in $2^{\text {nd }}, 3^{\text {rd }}$ and $4^{\text {th }}$ experimental groups than in the control group. In contrast, the incorporation of radiolabeled glucose into the total lipids was $19.1,12.0,11.6 \%$ lower in the $2^{\text {nd }}, 3^{\text {rd }}$ and $4^{\text {th }}$ groups than in the control group. Radiolabeled $\mathrm{CO}_{2}$ amounts formed during oxidation of glucose, palmitate and leucine were $19.4,50.1,18.6 \%$ higher, 19.3 , 20.3 and $20.4 \%$ higher, and $42.0,33.3,30.4 \%$ lower in muscle homogenates in the $2^{\text {nd }}, 3^{\text {rd }}, 4^{\text {th }}$ groups respectively than in the control group.

Our results suggest that the stimulating influence of fat supplementation in diets of calves on growth may be explained not only by the energetical effect of fats, but probably also by their decreasing effect on the amino acid catabolism and their increasing effect on the protein synthesis in the skeletal muscles. The source of dietary fats and the age of calves did not affect the results apparently. 